\title{
Comparative analysis of chemical and bacterial distribution of coastal lagoons and freshwater lakes in Turkish Thrace
}

\author{
Análisis comparativo de la distribución química y bacteriana de lagunas costeras y lagos de agua dulce en la Tracia Turca
}

\author{
Pinar Altinoluk-Mimiroglu' and Belgin Camur-Elipek² \\ ${ }^{1}$ Technology Research and Development Centre, Trakya University. Edirne, 22030. Turkey \\ ${ }^{2}$ Department of Biology, Faculty of Science, Trakya University. Edirne, 22030. Turkey \\ e-mail: pinar_altinoluk@yahoo.com.tr
}

Recibido: 03 de mayo de $2016 . \quad$ Aceptado: 21 de diciembre de 2017.

Altinoluk-Mimiroglu P. and B. Camur-Elipek. 2018. Comparative analysis of chemical and bacterial distribution of coastal lagoons and freshwater lakes in Turkish Thrace. Hidrobiológica 28 (1): 61-69. DOl: 10.24275/uam/izt/dcbs/hidro/2018v28n1/Altinoluk

\begin{abstract}
Background. Microbial contamination of water bodies is causing major environmental and public health concerns in developing countries. Bacterial inclusion of inland waters can be of allochthonous and/or autochthonous origins. Goals. The aim of this study was to determine and compare the microbial contamination with environmental factors controlling colonization of bacteria in lagoon-lakes and freshwater lakes. Methods. Two lagoon-lakes and two freshwater lakes in Turkish Thrace were chosen and sampling was undertaken from October 2014 to August 2015 at seasonal intervals. While total heterotrophic bacteria, E. coli, coliform, and fecal coliform bacteria distributions from allochthonous and autochthonous origins were determined, environmental conditions of the ecosystems were also measured. While the Bray-Curtis Similarity Index and the Correspondence Analysis with Abundance Plot Analyses were used to determine the similarities of the sampling habitats, the Spearman's Correlation Index was applied to clarify relationships between the environmental variables and the bacterial distribution. Results. The bacterial distribution was positively related to dissolved oxygen in one of the sampled lagoon-lakes $(r=1.0, p<0.01)$ and negatively correlated with total dissolved solids and salinity in one of the sampled freshwater lakes $(r=-0.95, p<0.01 ; r=-0.80, p<0.05$, respectively). Conclusions. This research indicated that the saline water of the lagoon-lakes has limited the number of bacteria when compared with freshwater lakes.
\end{abstract}

Keywords: bacteria, lagoon-lake, physicochemical parameters, Turkey

\section{RESUMEN}

Antecedentes. La contaminación microbiana de los cuerpos de agua está causando importantes problemas ambientales y de salud pública en los países en desarrollo. La incorporación de bacterias en aguas continentales puede tener origen alóctono y/o autóctono. Objetivos. Determinar y comparar la contaminación microbiana con los factores ambientales que controlan la colonización de bacterias en lagunas y lagos de agua dulce. Métodos. Se eligieron dos lagunas y dos lagos de agua dulce en la Tracia turca. El muestreo se realizó entre octubre de 2014 y agosto de 2015 en diferentes estaciones del año. Se determinó la distribución de las bacterias heterótrofas, $E$. coli, coliformes y coliformes fecales de orígen alóctono y autóctono, y también se midieron las condiciones ambientales de los ecosistemas. El Índice de similitud de Bray-Curtis y el Análisis de correspondencias con Abundance Plot Analyze se utilizaron para determinar las similitudes de Ios hábitats de muestreo; mientras que el índice de correlación de Spearman se aplicó para conocer las relaciones entre las variables ambientales y la distribución bacteriana. Resultados. La distribución bacteriana se relacionó positivamente con el oxígeno disuelto en una de las lagunas-lago muestreadas $(r=1.0, p<0.01)$ y se correlacionó negativamente con el total de sólidos disueltos y la salinidad en otro de los lagos de agua dulce muestreados $(r=-0.95, p<0.01 ; r=-0.80$, $p<0.05$, respectivamente). Conclusiones. Esta investigación indicó que el agua salina de las lagunas-lagos limita el número de bacterias en comparación con los lagos de agua dulce.

Palabras clave: bacteria, laguna-lago, parámetros fisicoquímicos, Turquía 


\section{INTRODUCTION}

Aquatic resources are natural environments in which various groups of organisms (including bacteria) can inhabit and develop. All aquatic ecosystems differ from each other in biological components, physical and chemical features, and quantitative or qualitative patterns. One of the biological components of aquatic environments is bacterial communities that are affected by environmental conditions from autochthonous and allochthonous origins. Bacterial populations play very important roles in some major tasks in aquatic ecosystems, i.e. they decompose organic material to support food webs and add nutrients to the water (Logue et al., 2016). Inland waters may be contaminated by human activities, sewage discharges or overflows (Doreen et al., 2015). Bacterial contamination may cause potential human health risks and adverse effects to ecosystems (Ehrhardt et al., 2016).

The composition of bacterial communities can be influenced by many factors including temperature, rainfall patterns, dissolved oxygen, $\mathrm{pH}$, turbidity, salinity, ions or heavy metal concentrations, toxic materials, and other environmental features in the basin. The water itself affects the distribution of bacterial populations within it through its physicochemical features and the environments from anthropogenic or geologic resources. Although some environments have specific vital requirements for bacteria, others can limit their existence. All types of surface waters, from freshwaters to salt waters, include bacterial communities in every zone of water bodies from the surface layer to the bottom deposits (Malecka \& Donderski, 2006). Bacteria from different sources enter the aquatic environments such as in soil, air or the digestive tract of organisms. The bacteria group has autotrophic, heterotrophic, and parasitic live forms that also exist in aquatic environments. Their distribution is affected by environmental conditions. Wastewaters from settlements and natural fertilizers from agricultural areas can lead to microbiological pollution in aquatic ecosystems. In addition to know about pathogenic microorganisms, it is important to recognize microorganisms that indicate contamination in water bodies, and $E$. coli is the main indicator of water contamination by wastewater (Kenar \& Altındis, 2001).

In this study, the sampled lagoon-lakes are located along the coast of the Aegean Sea in Saros Bay. The area was declared a wetland conservation zone of Meric-Ergene River Basin. The sampled freshwater lakes in this study are used as sources of tap and irrigation water of local settlements. It is reported that despite the ecological and sociocultural importance of the region, transformation of ecological quality is becoming more noticeable (Tok et al., 2015).

In this paper, the seasonal variability of autochthonous and allochthonous bacterial communities (total heterotrophic bacteria, coliform bacteria, fecal coliform bacteria and Escherichia coli bacteria) and physicochemical conditions of two different aquatic environments (two lagoon-lakes and two freshwater lakes) in the Turkish Thrace region were examined. In addition, the effects of environmental features on their distribution were evaluated statistically.

\section{MATERIALS AND METHODS}

Study area and sampling. The Turkish Thrace is located in Turkey's northwest and is known as European Turkey. The region is covered by settlements and agricultural areas where paddy, mustard, and other crops are cultivated. While the sampled lagoon-lakes that are semiconnected with sea water are located in the southwest part of the Sub Thrace Region and situated along the coast line of the Aegean Sea, the sampled freshwater lakes are located near the lagoon-lakes area and provide tap and irrigation water.

Water samples were taken between October 2014 and August 2015 from eight sites (Fig. 1). Stations 1 (40³5'51.6" N, $\left.26^{\circ} 15^{\prime} 19.9^{\prime \prime} \mathrm{E}\right)$ and $2\left(40^{\circ} 36^{\prime} 28.2^{\prime \prime} \mathrm{N}, 26^{\circ} 15^{\prime} 56.7^{\prime \prime} \mathrm{E}\right)$ were chosen in Tuzla lagoonlake, which is a very shallow coastal lagoon, separated by a small littoral bar with Saros Bay. This lagoon-lake has brackish to salt water features, with a mean depth of less than one meter, and is about $2.2 \mathrm{~km}$ in length and $1.2 \mathrm{~km}$ in width. Stations $3\left(40^{\circ} 43^{\prime} 27.3^{\prime \prime} \mathrm{N}, 26^{\circ} 04^{\prime} 24.4^{\prime \prime}\right.$ E) and 4 ( $40^{\circ} 42^{\prime} 48.8^{\prime \prime} \mathrm{N}, 26^{\circ} 05^{\prime} 05.0^{\prime \prime}$ E) were chosen in a closed lagoon, i.e., Dalyan lagoon-lake, which has livestock farming wastes surrounding it. The Dalyan lagoon-lake, no deeper than 1.7 meters, also has brackish to salt water features. This lake has a surface area of 250 ha. Stations $5\left(40^{\circ} 57^{\prime} 20.5^{\prime \prime} \mathrm{N}, 27^{\circ} 00^{\prime} 32.7^{\prime \prime} \mathrm{E}\right)$ and $6\left(40^{\circ} 56^{\prime} 47.6^{\prime \prime} \mathrm{N}\right.$, $\left.26^{\circ} 59^{\prime} 40.8^{\prime \prime} \mathrm{E}\right)$ were chosen in Karaidemir freshwater lake, which has many surrounding rural settlements and, thus, their sewage might be able to enter this system. This lake is used for irrigation and fisheries. The maximum lake capacity is $120.30 \mathrm{hm}^{3}$ and lake area is $15.50 \mathrm{~km}^{2}$. Stations 7 (40 $\left.47^{\prime} 37.4^{\prime \prime} \mathrm{N}, 26^{\circ} 46^{\prime} 20.5^{\prime \prime} \mathrm{E}\right)$ and 8 (40 48' 53.4' N, $\left.26^{\circ} 47^{\prime} 58.5^{\prime \prime} \mathrm{E}\right)$ were chosen in the Kadikoy freshwater lake reservoir, which is used for irrigation and tap water in the region. The maximum lake capacity is $65.68 \mathrm{hm}^{3}$ and its area is $6.20 \mathrm{~km}^{2}$.

Bacteriological surveys. We collected water samples from the sampling stations at a depth of about $20 \mathrm{~cm}$, placed them into sterile bottles with a capacity of $100 \mathrm{~mL}$, and immediately transported them to the laboratory in a container with ice; the temperature was about $+5^{\circ} \mathrm{C}$.

While the number of total heterotrophic bacteria was determined by the spread-plates method using plate-count agar, the others (total coliform and fecal coliform bacteria, E. coli) were determined using the method of Most Probable Number (MPN) (APHA, 1998). All inoculations were conducted in three parallel repetitions. Inoculums from the tubes showing fermentation were streaked on EMB agar. Isolated colonies of E.coli from EMB agar (round colonies with green metallic sheen) were confirmed by biochemical tests with IMVIC, where "I" is indole production from Tryptone broth, "M" and "V" are methyl red and the Voges Proskauer test from MR-VP broth and " $\mathrm{C}$ " is the citrate test from Simmon's Citrate agar (APHA, 1998). Isolates showing,,,++-- reaction for IMVIC test were confirmed as E. coli, respectively (June et al., 2016). The culture media (for presumptive, confirmed, and completed tests), and incubation conditions were given in Table 1.

Physicochemical surveys. In the field studies, while air and water temperatures, dissolved oxygen, $\mathrm{pH}$, conductivity, salinity, and total dissolved solids were measured using the Consort model C 5010 multiparameter device, the turbidity of the water at each station was measured by Secchi disk. Rainfall was also recorded during field studies.

The water samples held by the Nansen water sampler were transported to the laboratory in dark glass bottles with a capacity of 2 liters to evaluate the other parameters, while the nitrite nitrogen, nitrate nitrogen, phosphate, and sulphate were analyzed by the Metrohm lon Chromatography System 881 Compact IC Pro, equipped with a Metrohm 896 Professional Detector-Conductivity \& Amperomerty, and an automatic injector. This analytical technique was based on the USEPA method 300.1 


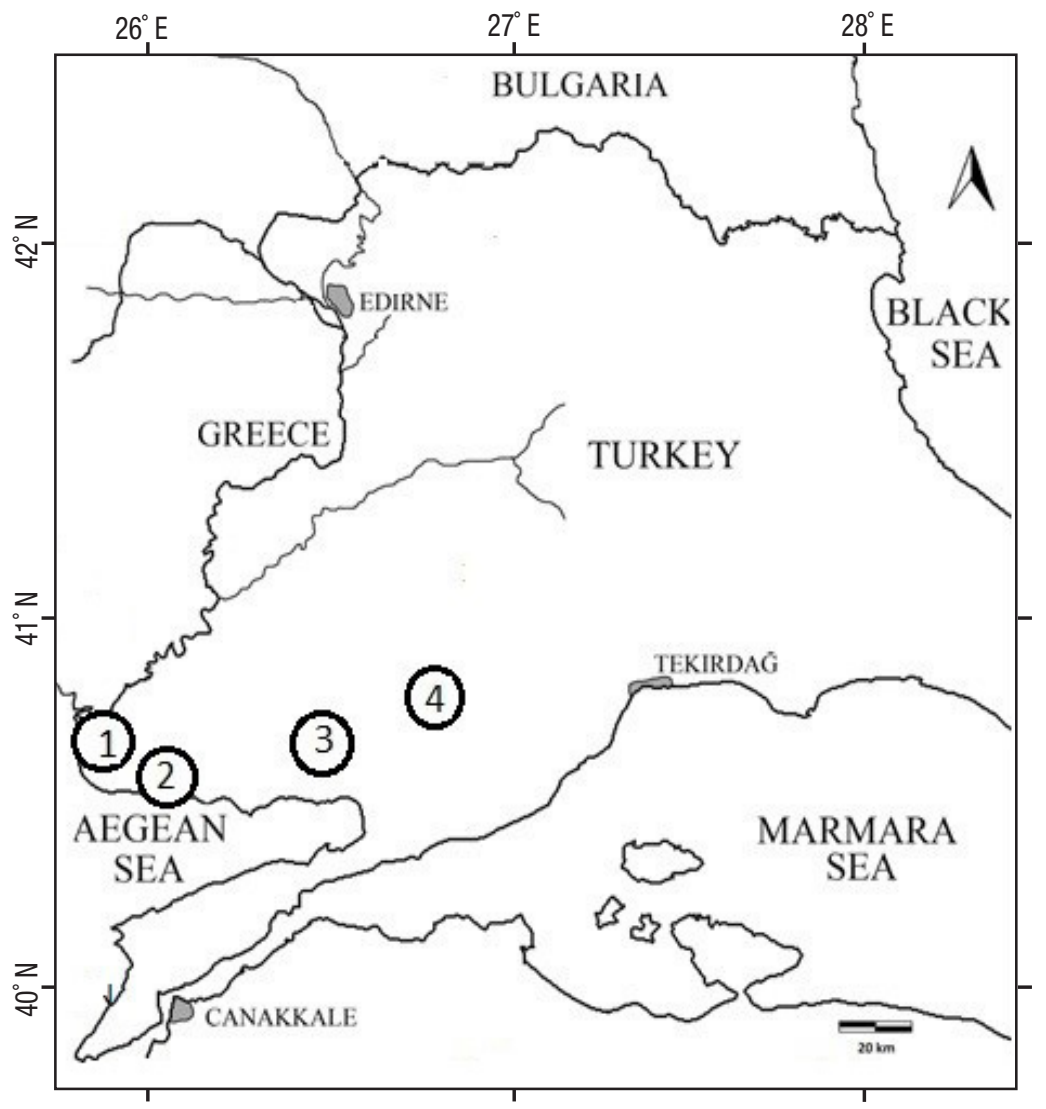

Figure 1. Locations of sampled water resources in Turkish Thrace. 1) Dalyan lagoon-lake. 2) Tuzla lagoon-lake. 3) Kadikoy freshwater lake. 4) Karaidemir freshwater lake.

(Hautman \& Munch, 1997). The trace elements like sodium, magnesium, aluminum, calcium, chromium, manganese, iron, cobalt, nickel, copper, zinc, arsenic, selenium, strontium, silver, cadmium, and lead, were analyzed by Agilent Technologies 7700 XX ICP-MS System in the TUTAGEM (Trakya University, Technology Research and Development Centre) laboratories. ICP-MS measurements and metal analysis were performed using the USEPA method 200.8 (Creed et al., 1994).

Statistical analysis. The relationships between the bacterial distributions and environmental features were explored by Spearman's Correlation Index (SPSS for Windows). In addition, reference was made to the Bray-Curtis Cluster Analyses to determine similarity rations among the sampling sites. The results were statistically supported by Correspondence Analysis and Abundance Plot Analysis.

\section{RESULTS AND DISCUSSION}

Data concerning the total number of heterotrophic bacteria (THB) occurring in the water of the sampled lakes is presented in Fig. 2. In this study, the greatest number of THB was found at the Kadikoy freshwater lake $\left(4.2 \times 10^{6} \mathrm{CFU} 100 \mathrm{~mL}^{-1}\right)$. The lowest average number of THB was found at Dalyan lagoon-lake $\left(4.0 \times 10^{1} \mathrm{CFU} 100 \mathrm{~mL}^{-1}\right)$. The greatest total number of THB was found in during the spring at sampled freshwater lakes; the lowest occurred during the summer at lagoon-lakes (Fig. 2). An average distribution of the number of THB was found at the Kadikoy freshwater lake $>$ Karaidemir freshwater lake $>$ Tuzla lagoon-lake $>$ Dalyan lagoon-lake, respectively (Fig. 3). As we can see, freshwater lakes have higher bacterial counts than lagoon-lakes. In addition, the results of the Bray-Curtis similarity index and Correspondence analysis supported these findings (Figs 4-5).

Existence of total coliform (TCB), fecal coliform (FCB), and E. coli was observed in all sampled water resources and during all sampling periods (Table 2).

The values of the physical and chemical parameters of the sampled lakes including air and water temperatures, dissolved oxygen, $\mathrm{pH}$, conductivity, salinity, total dissolved solids, turbidity, nitrite nitrogen, nitrate nitrogen, phosphate, sulphate, sodium, magnesium, aluminium, calcium, chromium, manganese, iron, cobalt, nickel, copper, zinc, arsenic, selenium, strontium, silver, cadmium, and lead levels appear in Table 3. Basically, among these parameters, water temperature showed obvious seasonal change: The water temperature ranged from $7.9^{\circ} \mathrm{C}$ to $28^{\circ} \mathrm{C}$ during the sampling period. The water of sampled lakes was slightly alkaline with $\mathrm{pH}$ values that varied between 7.74 and 9.08; D0 was recorded between 5.120 and $12.920 \mathrm{mg} \mathrm{L}^{-1}$, a congenial environment for biota. The conductivity records varied from 0.37 (Kadikoy freshwater lake, autumn) to $45.40 \mathrm{mS} \mathrm{cm}^{-1}$ (Dalyan lagoon-lake, summer). Salinity had a maximum of $0.3 \%$ in the freshwater lakes and $28.7 \%$ in the lagoon-lakes (Table 3). The climate was characterized by heavy rainfall during autumn and spring. 
Table 1. Culture media and incubation conditions used for counting bacteria (APHA, 1998) obtained at lakes in Turkey.

\begin{tabular}{|c|c|c|c|c|}
\hline Bacteria & Method & Culture Media & $\begin{array}{c}\text { Temperature } \\
\left({ }^{\circ} \mathrm{C}\right)\end{array}$ & $\begin{array}{l}\text { Time } \\
\text { (hours) }\end{array}$ \\
\hline Total Heterotrophic & Spread Plate & Plate Count Agar & $35 \pm 0.5$ & 48 \\
\hline \multirow{3}{*}{ Total Coliform } & \multirow{3}{*}{ Most Probable Number (MPN) } & LST Broth & $35 \pm 0.5$ & $24 \pm 2$ \\
\hline & & BGLBB Broth & $35 \pm 0.5$ & $24 \pm 2$ \\
\hline & & LST Broth & $35 \pm 0.5$ & $24 \pm 2$ \\
\hline \multirow[t]{5}{*}{ Fecal Coliform } & \multirow[t]{3}{*}{ Most Probable Number (MPN) } & BGLBB Broth & $35 \pm 0.5$ & $24 \pm 2$ \\
\hline & & EC Broth & $44.5 \pm 0.2$ & $24 \pm 2$ \\
\hline & & LST Broth & $35 \pm 0.5$ & $24 \pm 2$ \\
\hline & \multirow{2}{*}{ Most Probable Number (MPN) } & BGLBB Broth & $35 \pm 0.5$ & $24 \pm 2$ \\
\hline & & EC Broth & $44.5 \pm 0.2$ & $24 \pm 2$ \\
\hline \multirow{5}{*}{ E. coli } & & EC Broth with MUG & $44.5 \pm 0.2$ & $24 \pm 2$ \\
\hline & \multirow{4}{*}{$\begin{array}{l}\text { Confirmed and Completed } \\
\text { Test }\end{array}$} & EMB Agar & $35 \pm 0.5$ & $18-24$ \\
\hline & & Tryptone Broth & $35 \pm 0.5$ & $24 \pm 2$ \\
\hline & & MR-VP Broth & $35 \pm 0.5$ & $24-48$ \\
\hline & & Simmon's Citrate Agar & $35 \pm 0.5$ & $24-48$ \\
\hline
\end{tabular}

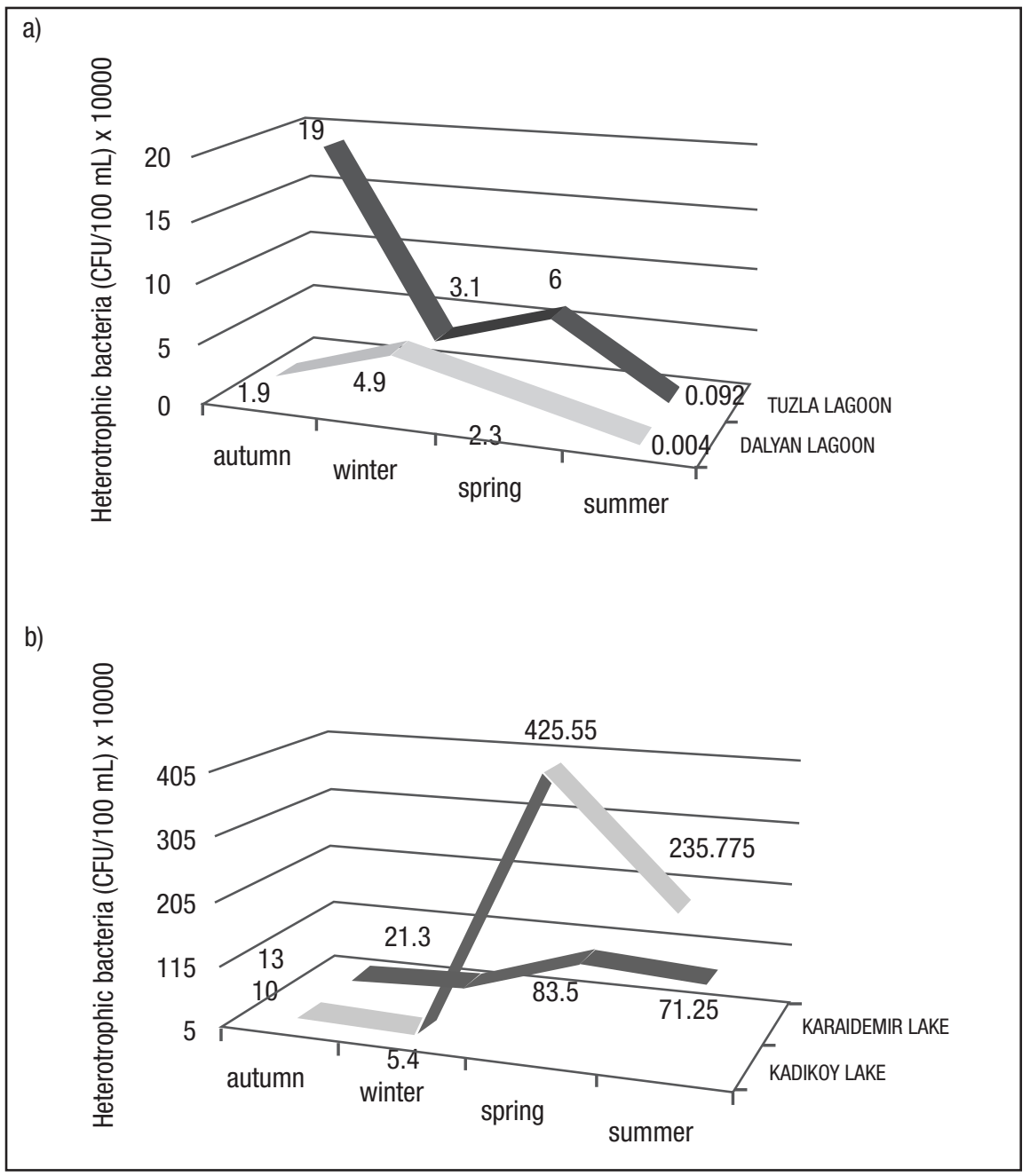

Figures 2a-b. Distribution of heterotrophic bacteria in the sampled lakes in Turkey. a) Lagoon-lakes; b) Freshwater lakes. 


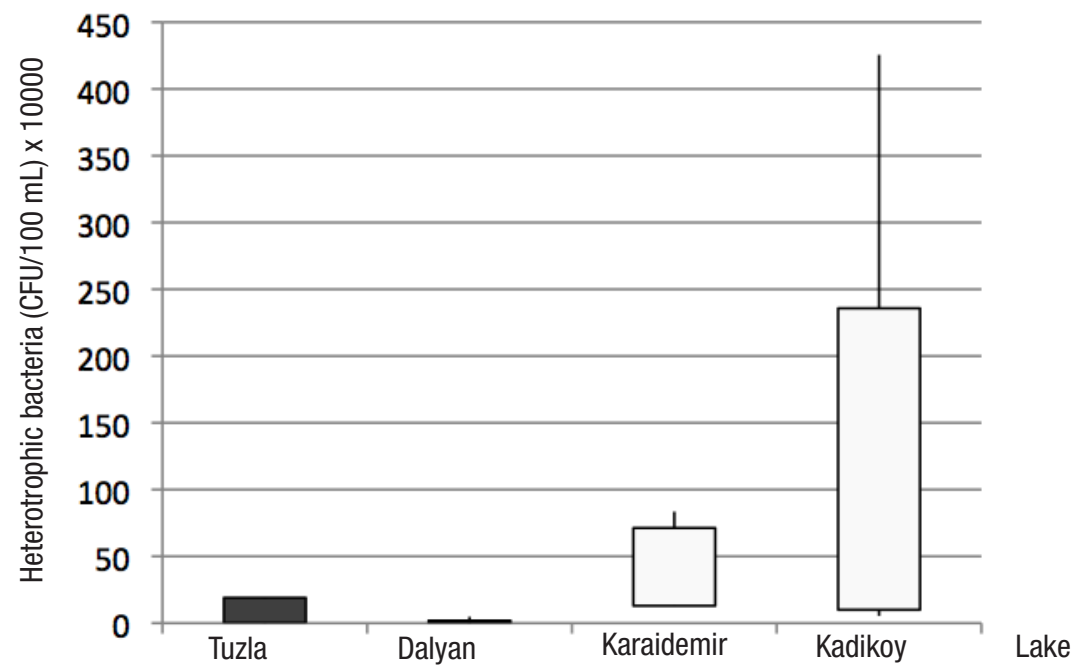

Figure 3. Average distribution of heterotrophic bacteria (CFU $100 \mathrm{~mL}^{-1}$ ) in the sampled lakes of Turkey at different seasons.

According to statistical analyses undertaken to determine the relationships between the bacteria counts and the environmental features of the sampled lakes, we found some results to be meaningful. Because of this evaluation, from the analysis at all sites, we determined that water and air temperature were positively related to THB counts $(r=$ $0.40, p<0.01$ ); salinity and $\mathrm{pH}$ were negatively correlated with THB counts $(r=-0.80, p<0.01 ; r=-0.60, p<0.01)$. However, there was no correlation whatsoever between metal values and THB.

In the Kadikoy freshwater lake, water temperature was found to have a positive relation with conductivity and salinity $(r=0.82$ and $r=$ 0.95 respectively, $p<0.01$ ), but a negative relation with dissolved oxygen $(r=-0.78, p<0.05)$. Also, the relationships between conductivity and salinity were found to have a positive correlation in the lake $(r=$ $0.77, p<0.05)$. In the Karaidemir freshwater lake, water temperature was found to have a negative relation with dissolved oxygen and nitratenitrogen ( $r=-0.93, p<0.01$ and $r=-0.79, p<0.05$, respectively). In addition, the relationship between dissolved oxygen and $\mathrm{pH}$ was found to have a negative correlation in the lake $(r=-0.82, p<0.05)$. In Dalyan lagoon-lake, water temperature was found to have a positive relation with total dissolved solids, magnesium, and calcium $(r=1.00, p<0.01)$. While $\mathrm{pH}$ and nitrite-nitrogen have a positive correlation, light permeability and nitrate-nitrogen have negative correlation in the lagoon ( $\mathrm{r}=$ $\pm 1.00, p<0.01$ ). In the Tuzla lagoon-lake, the water temperature was found to have a negative relation with $\mathrm{pH}$, light permeability and total dissolved solids ( $r=-1.00, p<0.01)$, but a positive relation with sulphate $(r=1.00, p<0.01)$. While the relationships between conductivity and salinity, between light permeability and $\mathrm{pH}$ were found to be positively correlated; sulphate showed significant negative correlation with light permeability and total dissolved solids $(r= \pm 1.00, p<0.01)$.

THB and its density have effects on the enrichment of water with organic substances that determine the trophic level of the body of water. Therefore, the number of bacteria in an aquatic ecosystem provides basic information for microbiological studies. Previous studies have shown that bacterial number depends on the autochthonic matter in clear water resources, made up of exometabolites of phyto- and zooplankton excretions as well as allochthonous matter, which enters the water through spring surface run-off and atmospheric precipitation (Jansson et al., 2000; Malecka \& Donderski, 2006).

When the counts of heterotrophic bacteria in the sampled lagoonlakes were evaluated by seasons, the highest count was observed in the autumn $\left(1.9 \times 10^{5}\right.$, Tuzla Lagoon). The maximum number of bacteria was found at freshwater lakes in the spring $\left(4.2 \times 10^{6}\right.$, Kadikoy Lake). This can be explained by an increase of organic material in the water during rainfall during these periods. Rainfall is an important factor in the bacterial contamination of water in urban areas due to runoff. Urban drainage systems and discharges during heavy rainfalls may have significant effects on the quality of receiving waters (Tryland et al., 2014).

Table 2. Total coliform (TCB), fecal coliform (FCB), and E.coli bacteria counts (MPN $100 \mathrm{~mL}^{-1}$ ) at lakes in Turkey sampled during different seasons.

\begin{tabular}{llcccc}
\hline Wutumn & & $\begin{array}{c}\text { Dalyan } \\
\text { lagoon-lake }\end{array}$ & $\begin{array}{c}\text { Tuzla } \\
\text { lagoon-lake }\end{array}$ & $\begin{array}{c}\text { Kadikoy } \\
\text { freshwater } \\
\text { lake }\end{array}$ & $\begin{array}{c}\text { Karaidemir } \\
\text { freshwater } \\
\text { lake }\end{array}$ \\
\hline \multirow{6}{*}{ Winter } & TCB & 2 & $<2$ & 900 & 70 \\
& FCB & 2 & $<2$ & 34 & 30 \\
& E. coli & 2 & $<2$ & 33 & 23 \\
& TCB & 2 & $<2$ & 16 & 190 \\
& FCB & $<2$ & $<2$ & 16 & 28 \\
& E. coli & $<2$ & $<2$ & 7 & 28 \\
& TCB & 4 & $<2$ & 815 & 151 \\
& FCB & 2 & $<2$ & 182 & 151 \\
& E. coli & 2 & $<2$ & 146 & 141 \\
Summer & TCB & $<20$ & $<20$ & 21 & 960 \\
& FCB & $<20$ & $<20$ & 17 & 610 \\
& E. coli & $<20$ & $<20$ & 12 & 205 \\
\hline
\end{tabular}


Heterotrophic bacteria and some coliforms are found naturally in environmental samples, but fecal coliforms and E. coli contamination occur in surface runoff due to the spread of fertilizers on agricultural land, farms, other areas where animal wastes are deposited, inadequate septic systems, sewer overflows, and wildlife (Dombek et al., 2000).

THB counts were found to be higher than TCB, FCB, and E. coli bacteria at each biotope. When the FCB and the $E$. coli bacteria numbers were evaluated by sampling stations, the highest values were recorded at freshwater lakes. This may be explained by some settlement sewage entering these systems. Furthermore, the lagoon-lakes that are the farthest from city centres have the lowest bacteriological numbers.

In the Tuzla lagoon-lake, the bacterial counts by seasons were found to be equal. This situation can be explained by the counts of TCB, $\mathrm{FCB}$, and E. coli that come from fecal matter. However, the high counts of total coliforms from other bacteria in the Kadikoy and Karaidemir freshwater lakes show that the total coliform group includes another bacterial presence, apart from the fecal bacteria.

Although total coliform bacteria in an aquatic environment can come from both allochthonous and autochthonous material, fecal and E.coli bacteria can reach the water from allochthonous resources. Thus, these bacterial findings point to pollution in the aquatic environment.

a)

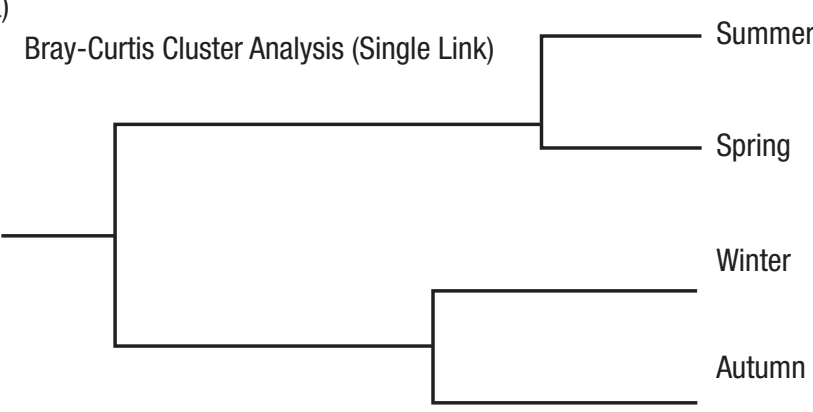

\begin{tabular}{lll}
\hline $0 \%$ Similarity & 50 & 100
\end{tabular}

b)
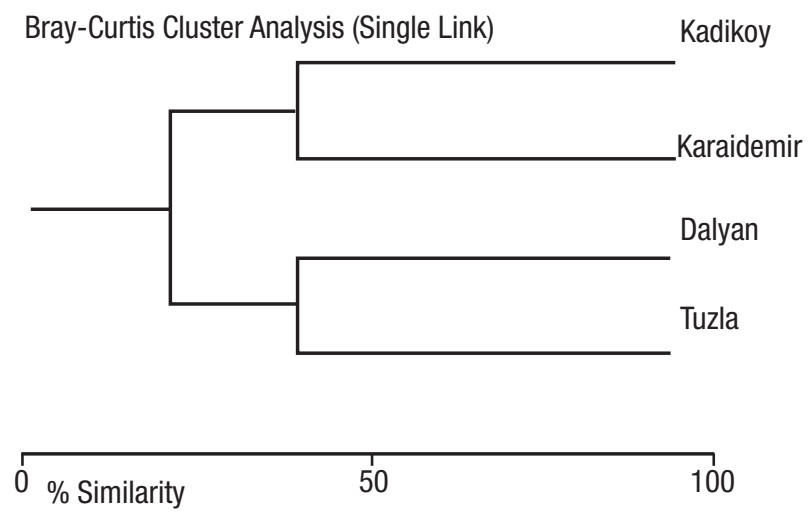

Figures 4a-b. Bray Curtis similarity dendrograms by seasons and the sampled lakes of Turkey, based on bacteria. a) Seasons. b) Lakes.
According to the Water Pollution Control Regulation (Anonymous, 2016) inland waters are divided in to four classes: high quality water, slightly polluted water, polluted water, and heavily polluted water. The numbers associated with total coliform for high quality, slightly polluted, polluted, and heavily polluted water are 100, 20000, 100000 and > $100000 \mathrm{MPN} 100 \mathrm{~mL}^{-1}$; fecal coliform numbers are 10, 200, 2000 and $>2000 \mathrm{MPN} 100 \mathrm{~mL}^{-1}$, respectively (Anonymous, 2016). According to the results, the water quality of the sampled sites was classified as high quality given the average number of coliform bacteria, while water at the Karaidemir freshwater lake was classified as slightly polluted, given the average number of fecal coliform bacteria. According to extracts from the WHO (2003) guideline, the number of total coliform bacteria in bathing waters should not be more than $10000 \mathrm{CFU} 100 \mathrm{ml}^{-1}$ of the water.

Swiatecki (1997) reported that seasonal changes in temperature are correlated with the dynamics of bacteria development in aquatic ecosystems. Furthermore, the processes governing the abundance in microbial community composition may greatly differ between habitats (Canfora et al., 2014; Herlemann et al., 2016). Much as low temperatures can lead to high ion concentrations, salt can affect, the distribution of bacteria (Swiatecki, 1997). In our study, water and air temperature values were directly proportional to THB counts. Salinity and the heterotrophic bacteria distribution were negatively related, according to the Spearman rank correlation test $(r=-0.80, p<0.01)$.

Salinity is a very important environmental factor for aquatic organisms because it can limit their lifespan (Peeters et al., 2011). Salinity is thought to influence the composition of natural bacterial communities (Crump et al., 2004). It is likely that bacteria remain active in the lagoon-lakes, but at a lower rate, due to increased salinity (Hyun et al., 1999). In lagoon-lakes, the primary adverse conditions are hypersalinity and osmotic stress (Aanderud et al., 2016). Similar results were obtained in this study. The low counts of heterotrophic bacteria in the sampled lagoon-lakes can be particularly explained by their salinities. The highest values of salinity were observed during the summer, because the amount of water decreases via evaporation and the intensity of dissolved materials increases, leading to the lowest bacterial distribution. In addition, we observed that light permeability in sampled lagoon-lakes was higher than in sampled freshwater lakes. Nutrients were found to have low quality levels in sampled ecosystems. Sulphate values, in particular, were found to register at a fourth quality level at lagoon-lakes during the summer.

The sampled lagoon-lakes at Meric Basin, are migratory stops and are important in preserving wildlife. The sampled freshwater lakes, located in the southwest of the Sub Thrace Region in Turkey, provide tap and irrigation water. In this study, we found those lakes that act as natural reserves are threatened by all types of pollution from settlements, as well as industrial and agricultural activities. The bacteriological quality of inland water is a concern to consumers, public health authorities and regulators (Odonkor \& Ampofo, 2013). Humans and livestock are sources of fecal contamination, and which gives rise to the highest risk of waterborne disease (Mokondoko et al., 2016). Therefore, to minimize the risk of pathogen microorganisms entering surface water, all farmbuilding drains need to be regularly maintained. Controlling the water flow from fields to surface water is one of the most important options to reduce nutrient pollution of inland water, because both nitrogen compounds and phosphorus contribute to eutrophication. 
Table 3. Mean values of physical and chemical variables in the sampled lakes in Turkey.

\begin{tabular}{|c|c|c|c|c|c|c|c|c|}
\hline & \multicolumn{4}{|c|}{ Dalyan Lagoon-Lake } & \multicolumn{4}{|c|}{ Tuzla Lagoon-Lake } \\
\hline & Autumn & Winter & Spring & Summer & Autumn & Winter & Spring & Summer \\
\hline A.T. $\left({ }^{\circ} \mathrm{C}\right)$ & 14.0 & 11.0 & 18.5 & 30.0 & 16.0 & 13.0 & 18.0 & 30.0 \\
\hline W.T. $\left({ }^{\circ} \mathrm{C}\right)$ & 15.2 & 9.1 & 21.4 & 26.0 & 15.9 & 10.0 & 23.5 & 28.0 \\
\hline D.0. $\left(\mathrm{mg} \mathrm{L}^{-1}\right)$ & 8.27 & 10.68 & 9.26 & 5.12 & 8.24 & 11.20 & 8.31 & 5.72 \\
\hline $\mathrm{pH}$ & 8.95 & 8.18 & 8.61 & 7.74 & 8.42 & 9.08 & 8.41 & 8.06 \\
\hline $\mathrm{EC}\left(\mathrm{mS} \mathrm{cm}^{-1}\right)$ & 0.78 & 0.95 & 13.79 & 45.40 & 6.47 & 14.50 & 42.50 & 45.00 \\
\hline Salinity (\%o) & 7.5 & 7.2 & 6.9 & 28.7 & 10.0 & 10.3 & 10.9 & 28.4 \\
\hline $\operatorname{TDS}\left(\mathrm{g} \mathrm{L}^{-1}\right)$ & 1.64 & 0.16 & 2.08 & 26.40 & 1.89 & 0.16 & 2.05 & 25.80 \\
\hline Turbidity (cm) & 110.0 & 76.0 & 60.0 & 75.0 & 90.0 & 100.0 & 65.0 & 40.0 \\
\hline $\mathrm{N}-\mathrm{NO}_{2}-\left(\mathrm{mg} \mathrm{L}^{-1}\right)$ & 0.16 & 0.07 & 0.12 & 0.06 & 0.001 & 0.001 & 0.001 & 0.00 \\
\hline $\mathrm{N}-\mathrm{NO}_{3}^{2}-\left(\mathrm{mg} \mathrm{L}^{-1}\right)$ & 0.62 & 3.98 & 12.93 & 4.67 & 6.06 & 6.53 & 6.78 & 2.17 \\
\hline Phosphate (mg L-1) & 8.16 & 0.005 & 11.19 & 0.10 & 0.09 & 0.72 & 0.09 & 0.30 \\
\hline Sulphate $\left(\mathrm{mg} \mathrm{L}^{-1}\right)$ & 0.05 & 79.49 & 117.21 & 4039.69 & 0.06 & 0.03 & 2.14 & 2870.66 \\
\hline Sodium $\left(\mathrm{mg} \mathrm{L}^{-1}\right)$ & 20630.68 & 0.67 & 245.17 & 167613.92 & 38.66 & 3.33 & 923.22 & 164956.12 \\
\hline Magnesium (mg L-1) & 10.37 & 0.22 & 32.76 & 11636.98 & 37.36 & 0.49 & 119.83 & 12674.93 \\
\hline Aluminum $\left(\mathrm{mg} \mathrm{L}^{-1}\right)$ & 0.20 & 0.78 & 0.89 & 1.63 & 0.39 & 0.73 & 1.63 & 4.99 \\
\hline Calcium (mg L-1) & 0.03 & 0.47 & 8.70 & 680.22 & 5.74 & 0.42 & 11.20 & 678.96 \\
\hline Chromium ( $\left.\mu \mathrm{g} \mathrm{L}^{-1}\right)$ & 12.18 & 9.66 & 18.28 & 6174.98 & 15.33 & 9.61 & 22.88 & 6053.18 \\
\hline Manganese $\left(\mu g \mathrm{~L}^{-1}\right)$ & 21.78 & 12.37 & 31.50 & 2179.86 & 29.20 & 12.29 & 30.38 & 942.42 \\
\hline Iron $\left(\mathrm{mg} \mathrm{L}^{-1}\right)$ & 0.95 & 0.35 & 1.29 & 29.33 & 1.02 & 0.36 & 1.45 & 34.71 \\
\hline Cobalt $\left(\mu \mathrm{g} \mathrm{L}^{-1}\right)$ & 0.99 & 4.65 & 10.46 & 87.92 & 1.96 & 4.65 & 10.11 & 98.86 \\
\hline Nickel $\left(\mu \mathrm{g} \mathrm{L}^{-1}\right)$ & 46.02 & 11.07 & 16.86 & 219.47 & 70.39 & 11.08 & 31.17 & 251.56 \\
\hline Copper ( $\left.\mu \mathrm{L}^{-1}\right)$ & 54.47 & 33.08 & 32.90 & 118.81 & 33.11 & 33.27 & 75.82 & 122.73 \\
\hline $\operatorname{Zinc}\left(\mu \mathrm{g} \mathrm{L}^{-1}\right)$ & 109.80 & 197.29 & 66.36 & 399.30 & 108.27 & 204.89 & 80.51 & 403.55 \\
\hline Arsenic $\left(\mu \mathrm{g} \mathrm{L}^{-1}\right)$ & 3.85 & 3.71 & 4.62 & 291.19 & 3.37 & 3.81 & 4.10 & 247.58 \\
\hline Selenium $\left(\mu \mathrm{g} \mathrm{L}^{-1}\right)$ & 0.03 & 0.02 & 0.14 & 2.89 & 25.05 & 17.59 & 155.03 & 2821.06 \\
\hline Strontium (mg L-1) & 0.17 & 0.02 & 0.19 & 107.32 & 0.39 & 0.02 & 0.60 & 99.33 \\
\hline Silver $\left(\mu \mathrm{g} \mathrm{L}^{-1}\right)$ & 17.62 & 6.33 & 16.51 & 73.75 & 17.28 & 3.04 & 17.02 & 32.41 \\
\hline Cadmium $\left(\mu \mathrm{g} \mathrm{L}^{-1}\right)$ & 1.94 & 5.03 & 3.29 & 15.05 & 2.17 & 5.42 & 3.38 & 10.002 \\
\hline \multirow[t]{3}{*}{ Lead $\left(\mu \mathrm{g} \mathrm{L}^{-1}\right)$} & 49.42 & 58.76 & 57.34 & 79.95 & 49.06 & 62.53 & 55.29 & 45.12 \\
\hline & \multicolumn{4}{|c|}{ Kadikoy Freshwater Lake } & \multicolumn{4}{|c|}{ Karaidemir Freshwater Lake } \\
\hline & Autumn & Winter & Spring & Summer & Autumn & Winter & Spring & Summer \\
\hline A.T. $\left({ }^{\circ} \mathrm{C}\right)$ & 17.0 & 12.0 & 21.5 & 34.5 & 17.0 & 12.0 & 20.3 & 33.5 \\
\hline W.T. $\left({ }^{\circ} \mathrm{C}\right)$ & 17.9 & 7.9 & 20.3 & 25.5 & 20.4 & 9.7 & 20.0 & 26.0 \\
\hline D.0. $\left(\mathrm{mg} \mathrm{L}^{-1}\right)$ & 7.79 & 12.92 & 9.37 & 8.21 & 7.35 & 11.94 & 8.95 & 6.91 \\
\hline $\mathrm{pH}$ & 8.32 & 8.64 & 8.56 & 8.43 & 8.45 & 8.23 & 8.46 & 8.54 \\
\hline $\mathrm{EC}\left(\mathrm{mS} \mathrm{cm}^{-1}\right)$ & 0.37 & 0.44 & 0.62 & 0.70 & 0.38 & 0.52 & 0.77 & 0.74 \\
\hline Salinity $(\% 0)$ & 0.1 & 0.1 & 0.2 & 0.3 & 0.1 & 0.1 & 0.2 & 0.3 \\
\hline TDS $\left(\mathrm{g} \mathrm{L}^{-1}\right)$ & 1.98 & 0.88 & 1.18 & 0.38 & 2.06 & 0.85 & 1.18 & 0.40 \\
\hline Light Perm. (cm) & 60.0 & 67.5 & 60.0 & 87.0 & 70.0 & 51.5 & 36.5 & 49.5 \\
\hline $\mathrm{N}-\mathrm{NO}_{2}-\left(\mathrm{mg} \mathrm{L}^{-1}\right)$ & 0.13 & 0.05 & 0.12 & 0.17 & 0.11 & 0.05 & 0.15 & 0.10 \\
\hline $\mathrm{N}-\mathrm{NO}_{3}^{2}-\left(\mathrm{mg} \mathrm{L}^{-1}\right)$ & 1.97 & 5.50 & 6.51 & 1.86 & 3.09 & 10.36 & 9.14 & 3.01 \\
\hline Phosphate (mg L-1) & 0.17 & 0.18 & 0.19 & 0.07 & 0.98 & 0.56 & 0.60 & 0.27 \\
\hline Sulphate $\left(\mathrm{mg} \mathrm{L}^{-1}\right)$ & 51.26 & 56.66 & 51.04 & 69.79 & 111.87 & 109.29 & 101.50 & 110.19 \\
\hline Sodium $\left(\mathrm{mg} \mathrm{L}^{-1}\right)$ & 16881.54 & 13.89 & 19.07 & 606.46 & 17.71 & 34.47 & 35.94 & 843.60 \\
\hline Magnesium $\left(\mathrm{mg} \mathrm{L}^{-1}\right)$ & 22.80 & 14.91 & 18.17 & 461.33 & 9.39 & 18.97 & 17.43 & 436.68 \\
\hline Aluminium $\left(\mathrm{mg} \mathrm{L}^{-1}\right)$ & 0.56 & 0.43 & 0.99 & 8.21 & 0.20 & 0.45 & 1.05 & 5.33 \\
\hline Calcium (mg L-1) & 3.53 & 3.86 & 16.72 & 159.58 & 2.78 & 5.20 & 14.58 & 166.34 \\
\hline Chromium ( $\left.\mu \mathrm{g} \mathrm{L}^{-1}\right)$ & 14.66 & 5.58 & 19.38 & 226.18 & 11.58 & 6.23 & 20.01 & 256.97 \\
\hline Manganese $\left(\mu \mathrm{g} \mathrm{L}^{-1}\right)$ & 13.20 & 8.62 & 31.98 & 436.09 & 17.22 & 8.77 & 59.29 & 390.69 \\
\hline Iron $\left(\mathrm{mg} \mathrm{L}^{-1}\right)$ & 1.01 & 0.18 & 2.11 & 20.07 & 0.96 & 0.19 & 2.13 & 19.30 \\
\hline Cobalt ( $\left.\mu \mathrm{g} \mathrm{L}^{-1}\right)$ & 1.03 & 42.48 & 6.38 & 23.86 & 0.82 & 39.66 & 6.67 & 21.08 \\
\hline Nickel $\left(\mu \mathrm{g} \mathrm{L} \mathrm{L}^{-1}\right)$ & 44.44 & 6.82 & 54.91 & 195.80 & 40.79 & 7.41 & 26.11 & 190.25 \\
\hline Copper ( $\left.\mu \mathrm{g} \mathrm{L}^{-1}\right)$ & 31.81 & 24.23 & 35.53 & 73.75 & 33.48 & 32.24 & 35.77 & 74.00 \\
\hline Zinc $\left(\mu \mathrm{g} \mathrm{L}^{-1}\right)$ & 96.79 & 95.11 & 87.72 & 262.52 & 103.87 & 108.88 & 65.69 & 330.64 \\
\hline Arsenic $\left(\mu \mathrm{g} \mathrm{L}^{-1}\right)$ & 9.48 & 5.24 & 5.73 & 31.44 & 3.75 & 6.45 & 6.16 & 50.55 \\
\hline Selenium ( $\left.\mu \mathrm{g} \mathrm{L}^{-1}\right)$ & 28.10 & 12.30 & 361.41 & 1582.43 & 25.57 & 11.58 & 359.47 & 1527.48 \\
\hline Strontium (mg L-1) & 11.67 & 0.04 & 0.22 & 4.36 & 0.17 & 0.05 & 0.25 & 4.65 \\
\hline Silver $\left(\mu g \mathrm{~L}^{-1}\right)$ & 21.88 & 140.76 & 18.44 & 22.11 & 15.68 & 227.10 & 17.94 & 14.46 \\
\hline Cadmium ( $\left.\mu \mathrm{g} \mathrm{L}^{-1}\right)$ & 2.09 & 3.67 & 3.89 & 5.81 & 2.27 & 3.53 & 3.87 & 6.04 \\
\hline Lead $\left(\mu \mathrm{g} \mathrm{L}^{-1}\right)$ & 49.06 & 40.77 & 58.38 & 56.87 & 50.09 & 40.94 & 58.65 & 45.82 \\
\hline
\end{tabular}




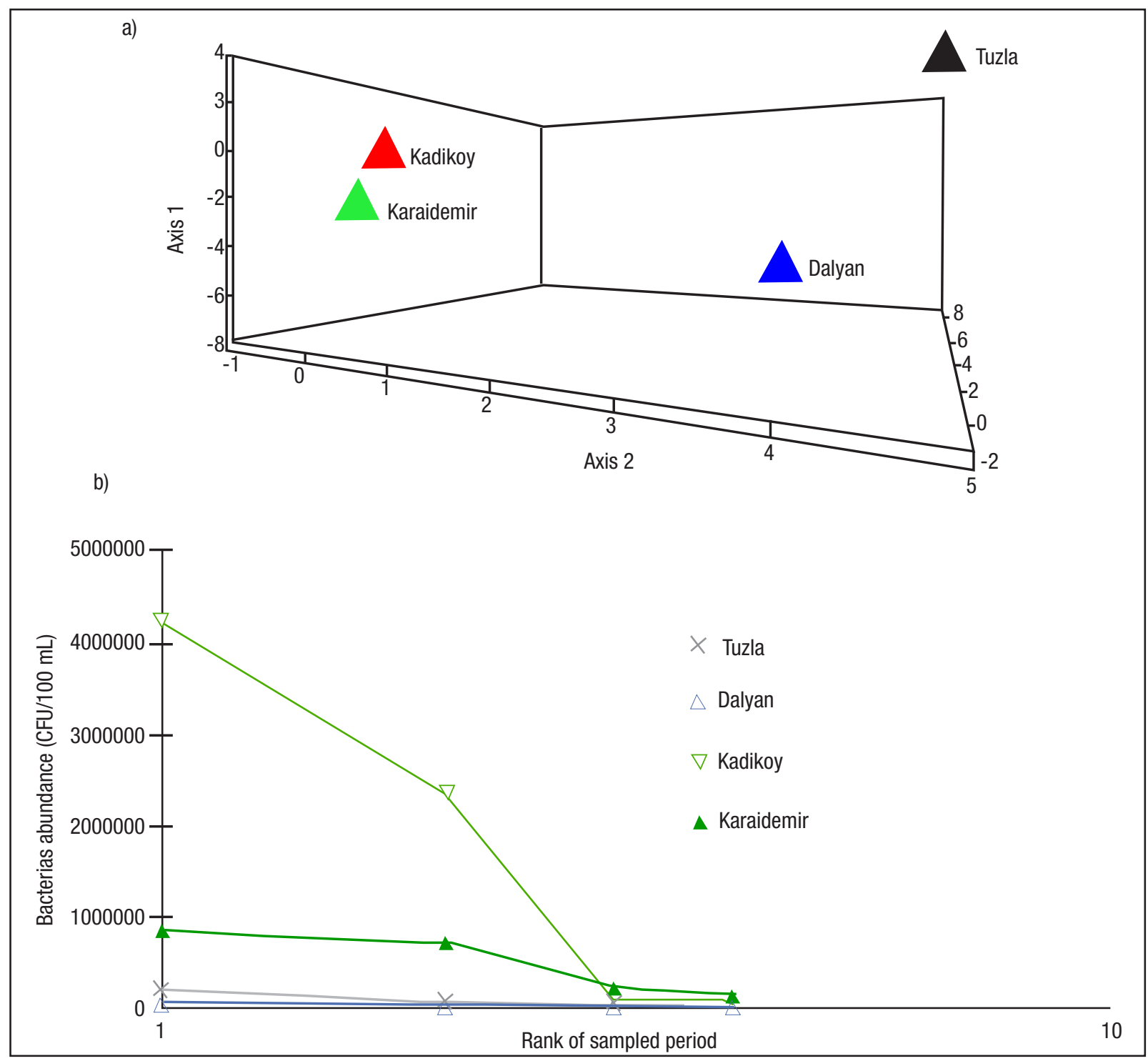

Figures 5a-b. a) Correspondence analysis, and b) Abundance Plot diagrams of bacteria numbers in the sampled lakes in Turkey.

In conclusion, bacterial populations play significant roles in organic matter decomposition in aquatic environments. They can occur from allochthonous or autochthonous resources, and some environmental conditions can limit their distribution in aquatic environments.

This study may lead to further researches on monitoring of bacterial composition of different water resources in Turkish Thrace. Furthermore, we suggest that these studies continue periodically, and some quality parameters and bacteriological processes should be monitored in aquatic environments.

\section{ACKNOWLEDGEMENTS}

This study is a part of the first author's PhD thesis, which has been supported by the Research Fund of Trakya University with project number TUBAP 2014/54.

\section{REFERENCES}

AAnderud, Z. T., J. C. VerT, J. T. Lennon, T. W. MAgnusson, D. P. BreAkWeLL \& A. R. HARKER. 2016. Bacterial dormancy is moreprevalent in freshwater than hypersaline lakes. Frontiers in Microbiology 7: 853. DOI:10.3389/fmicb.2016.00853.

AnonyMous. 2016. Yerustu Su Kalitesi Yonetmeligi, (Water Pollution Control Regulation). Official Gazette No: 29797 of 10 August 2016, Ankara, Turkey.

APHA. 1998. Standard Methods for the examination of water and waste water. 20th Edition. American Public Health Association, Washington, D.C.

Canfora L., G. Bacci, F. Pinzari, G. L. Papa, C. Dazzi \& A. Benedetti. 2014. Salinity and bacterial diversity: to what extent does the concentration 
of salt affect the bacterial community in a saline soil? Plos One 9(9): 1-15. D0I:10.1371/journal.pone.0106662.

Creed, J. T., C. A. Brockhoff \& T. D. Martin. 1994. Determination of trace elements in waters and wastes by inductively coupled plasmamass spectrometry, Method 200.8, Revision 5.4: US Environmental Protection Agency, $61 \mathrm{p}$.

Crump, B. C., C. S. Hopkinson, M. L. Sogin \& J. E. Hobbie. 2004. Microbial biogeography along an estuarine salinity gradient: combined influences of bacterial growth and residence time. Applied Environmental Microbiology 70 (3): 1494-1505. DOI:10.1128/AEM.70.3.14941505.2004.

Dombek, P. E., L. K. Johnson, S. T. Zimmerley \& M. J. SADOWSky. 2000. Use of repetitive DNA sequences and the PCR to differentiate Escherichia coli isolates from human and animal sources. Applied and Environmental Microbiology 66 (6): 2572-2577. DOI:10.1128/AEM.66.6.25722577.2000 .

Doreen, N., J. Окот-Окumu \& F. J. MuYodı. 2015. Microbial safety assessment of recreation water at Lake Nabugabo, Uganda. African Journal of Environmental Science and Technology 9 (10): 773-782. DOI:10.5897/AJEST2015.1979.

Ehrhardt, J., A. S. Alabi, P. G. Kremsner, W. Rabsch, K. Becker, F. T. Foguim, T. Kuczius, M. Esen \& F. Schaumburg. 2017. Bacterial contamination of water samples in Gabon, 2013. Journal of Microbiology, Immunology and Infection 50 (5): 718-722. D0I:10.1016/j.jmii.2016.03.009.

Hautman, D. P. \& D. J. Munch, D. J., 1997. Method 300.1 Determination of inorganic anions in drinking water by ion chromatography. EPA: Ohio.

Herlemann, D. P. R., D. Lundin, A. F. Andersson, M. Labrenz \& K. Jürgens. 2016. Phylogenetic signals of salinity and season in bacterial community composition across the salinity gradient of the Baltic Sea. Frontiers in Microbiology 7: 1883. D0I:10.3389/fmicb.2016.01883.

Hyun, J. H., J. K. Сhol, K. H. Chung, E. J. Yang \& M. K. Kim. 1999. Tidally induced changes in bacterial growth and viability in the macrotidal Han River estuary, Yellow Sea. Estuarine Coastal and Shelf Science. 48 (2): 143-153. D0I:10.1006/ecss.1998.0421.

Jansson, M., A. K. Bergström, P. Blomovist \& S. Drakare. 2000. Allochthonous organic carbon and phytoplankton/bacterioplankton production relationships in lakes. Ecology 81 (11): 3250-3255. DOI:10.1890/0012-9658(2000)081[3250:AOCAPB]2.0.C0;2.
JuNE, M., O. PAUL \& K. KIPLAGAT. 2016. Bacteriological quality of water from selected water sources in Samburu South - Kenya. Imperial Journal of Interdisciplinary Research 2 (9): 310-316. ISSN: 2454-1362.

KENAR, B. \& M. ALtindIS. 2001. Hygenic quality investigation of both drinking and tap-waters in Afyon. The Medical Journal of Kocatepe 2: 269-274. D0l:10.18229/ktd.54525.

Logue, J. B., C. A. Stedmon, A. M. Kellerman, N. J. Nielsen, A. F. Andersson, H. LAUdON, E. S. LINDSTRÖM \& E. S. KRITZBERG. 2016. Experimental insights into the importance of aquatic bacterial community composition to the degradation of dissolved organic matter. The ISME Journal 10 (3): 533-545. D0l:10.1038/ismej.2015.131.

MAEECKA, M. \& W. DonDERSKI. 2006. Heterotrophic bacteria inhibiting water of the river Brda on the Bydgoszcz town section. Baltic Coastal Zone 10: 31-46. ISSN 1643-0115.

Mokondoko, P., R. H. Manson \& 0. Pérez-Maqueo. 2016. Assessing the service of water quality regulation by quantifying the effects of land use on water quality and public health in central Veracruz, Mexico. Ecosystem Services 22: 161-173. D0I:10.1016/j.ecoser.2016.09.001.

OdonkoR, S. T. \& J. K. Ampofo. 2013. Escherichia coli as an indicator of bacteriological quality of water: an overview. Microbiology $R e$ search 4 (1): 2. D0l:10.4081/mr.2013.e2.

Peeters, K., D. A. Hodgson, P. Convey \& A. Willems. 2011. Culturable diversity of heterotrophic bacteria in Forlidas Pond (Pensacola Mountains) and Lundström Lake (Shackleton Range), Antarctica. Microbial Ecology 62 (2): 399-413. D0I:10.1007/s00248-011-9842-7.

SWIATECKI, A. 1997. Spatial and seasonal changes in bacterioplankton of heated Koninskie lakes. Archives of Polish Fisheries 5 (1): 167-182.

ToK, E., A. S. D. Günay \& A. Ç. T. TuRAn. 2016. A case study in natural coastline of Enez-Kesan districts by using natural threshold analysis. Journal of Ocean \& Coastal Management 118: 129-138. D0I:10.1016/j.ocecoaman.2015.07.030.

Tryland, I., M. Myrmel, Ø. Østensvik, A. C. Wennberg \& L. J. Robertson. 2014. Impact of rainfall on the hygienic quality of blue mussels and water in urban areas in the Inner Oslofjord, Norway. Marine Pollution BuIletin 85 (1): 42-49. D0l:10.1016/j.marpolbul.2014.06.028.

World Health Organization. 2003. Guidelines for safe recreational water environments. Volume 1: coastal and fresh waters. World Health Organization. 